\title{
Sarcopenic Obesity, Insulin Resistance, and Their Implications in Cardiovascular and Metabolic Consequences
}

\author{
So-hyeon Hong and Kyung Mook Choi * \\ Division of Endocrinology and Metabolism, Department of Internal Medicine, College of Medicine, \\ Korea University, Seoul 08308, Korea; kicara@gmail.com \\ * Correspondence: medica7@gmail.com; Tel.: +82-2-2626-3043
}

Received: 7 December 2019; Accepted: 10 January 2020; Published: 13 January 2020

check for updates

\begin{abstract}
The prevalence of sarcopenic obesity is increasing worldwide, particularly amongst aging populations. Insulin resistance is the core mechanism of sarcopenic obesity and is also associated with variable cardiometabolic diseases such as cardiovascular disease, type 2 diabetes mellitus, and non-alcoholic fatty liver disease. Fat accumulation in muscle tissue promotes a proinflammatory cascade and oxidative stress, leading to mitochondrial dysfunction, impaired insulin signaling, and muscle atrophy. To compound the problem, decreased muscle mass aggravates insulin resistance. In addition, the crosstalk between myokines and adipokines leads to negative feedback, which in turn aggravates sarcopenic obesity and insulin resistance. In this review, we focus on the molecular mechanisms linking sarcopenic obesity and insulin resistance with various biological pathways. We also discuss the impact and mechanism of sarcopenic obesity and insulin resistance on cardiometabolic disease.
\end{abstract}

Keywords: sarcopenic obesity; insulin resistance; cardiometabolic disease

\section{Introduction}

Aging and obesity are the common public health issues worldwide. People older than 65 years comprise $13 \%$ of the global population, and this percentage is increasing at a more rapid rate compared to the percentage of any other age group [1]. With aging, the loss of muscle mass and strength occurs naturally, and is defined as primary sarcopenia. In addition, secondary sarcopenia can develop because of physical inactivity, malnutrition, and diseases, such as neurodegenerative disease, endocrine disease, or malignancy [2]. Reduced muscle mass synergistically accompanies accumulation of fat mass, resulting in sarcopenic obesity [3]. Compared to obesity alone, sarcopenic obesity is associated with a heightened risk of adverse health outcomes, such as disability or impairment, cardiometabolic diseases, other comorbidities, and mortality [4-7].

Cardiometabolic diseases, including cardiovascular diseases, type 2 diabetes mellitus, and non-alcoholic fatty liver disease (NAFLD), are the leading causes of death worldwide. Among several risk factors, obesity, excess calorie intake, and low levels of physical activity are the main contributors [8], and insulin resistance (IR) is a common mechanism associated with the disease [9]. IR is the core of the pathophysiological characteristics of sarcopenic obesity. Skeletal muscle is the largest insulin-sensitive tissue and has the largest requirement for postprandial glucose through insulin dependent mechanism. Hence, impaired insulin signaling is commonly observed in sarcopenic obesity [10,11].

In this review, we describe the molecular pathogenesis of sarcopenic obesity with a particular focus on IR. We discuss its roles in cardiometabolic diseases, including atherosclerosis, cardiovascular disease, chronic heart failure, type 2 diabetes mellitus, metabolic syndrome, and NAFLD. 


\section{Sarcopenia and Sarcopenic Obesity}

\subsection{Definition}

Sarcopenia presents as a decline in skeletal muscle mass and strength. This decline is part of a normal physiological aging process; however, several factors exacerbate this situation, including low physical activity, inadequate nutrition, neurodegenerative disease, and inflammatory conditions. These factors result in increasing frailty and an increased risk of mortality [2,12]. Sarcopenic obesity, a combination of sarcopenia and obesity, is a concurrence of muscle loss and body fat increment. This body composition change brings unchanged or similar body weight or BMI; however, the change shifts toward unfavorable status, including reduced baseline metabolic rate, decreased mitochondrial number and volume, and increased oxidative stress, which exacerbates the vicious cycle [13]. This complex disorder results in a 2-3 times higher risk of functional disability than either sarcopenia or obesity alone [14].

The definition of sarcopenic obesity has not been universally established, and there are various diagnostic criteria for sarcopenia and obesity (Table 1). We previously reported that different definitions of sarcopenia resulted in differential impact on cardiometabolic risk factors. [15].

Table 1. Diagnostic criteria for sarcopenic obesity.

\begin{tabular}{|c|c|c|}
\hline Study & Definition of Sarcopenia & Definition of Obesity \\
\hline \multirow{2}{*}{$\begin{array}{l}\text { EWGSOP2 [2] } \\
\text { Use the SARC-F questionnaire to } \\
\text { find subjects with sarcopenia }\end{array}$} & $\begin{array}{l}\text { Decreased muscle mass and Decreased muscle } \\
\text { strength or performance }\end{array}$ & \multirow[t]{2}{*}{ NA } \\
\hline & $\begin{array}{l}\text { Muscle mass measurement ASM }<20 \mathrm{~kg}(\mathrm{M}), \\
15 \mathrm{~kg}(\mathrm{~W}) \mathrm{ASM} / \text { height }^{2}<7.0 \mathrm{~kg} / \mathrm{m}^{2}(\mathrm{M}), \\
<6.0 \mathrm{~kg} / \mathrm{m}^{2}(\mathrm{~W})(\mathrm{DXA}) \\
\text { Muscle strength measurement Hand grip } \\
\text { strength }<27 \mathrm{~kg}(\mathrm{M}),<16 \mathrm{~kg}(\mathrm{~W}) \text { Chair stand } \\
>15 \mathrm{~s} \text { for five rises } \\
\text { Performance measurement Gait speed } \leq 0.8 \mathrm{~m} / \mathrm{s} \\
\text { SPPB } \leq 8 \mathrm{TUG} \geq 20 \mathrm{~s} 400 \mathrm{~m} \text { walk test } \\
\text { Non-completion or } \geq 6 \text { min for completion }\end{array}$ & \\
\hline $\begin{array}{l}\text { New Mexico Aging Process Study } \\
{[16]}\end{array}$ & $\begin{array}{l}\text { ASM/height }{ }^{2}<7.26 \mathrm{~kg} / \mathrm{m}^{2}(\mathrm{M}),<5.45 \mathrm{~kg} / \mathrm{m}^{2}(\mathrm{~W}) \\
\text { (DXA) }\end{array}$ & $\begin{array}{l}\text { Body fat }>27 \%(\mathrm{M}) \\
\quad>38 \%(\mathrm{~W})\end{array}$ \\
\hline NHANES III [17] & ALM/height ${ }^{2}<9.12 \mathrm{~kg} / \mathrm{m}^{2}(\mathrm{M}),<6.53 \mathrm{~kg} / \mathrm{m}^{2}(\mathrm{~W})$ & $\begin{array}{c}\text { Body fat }>27 \%(\mathrm{M}) \\
>38 \%(\mathrm{~W})\end{array}$ \\
\hline FNIH [18] & ALM < $19.75 \mathrm{~kg}(\mathrm{M}),<15.02 \mathrm{~kg}(\mathrm{~W})(\mathrm{DXA})$ & NA \\
\hline \multirow{2}{*}{$\begin{array}{l}\text { Asian Working Group for } \\
\text { Sarcopenia [19] }\end{array}$} & $\begin{array}{l}\text { Decreased muscle mass and Decreased muscle } \\
\text { strength or performance }\end{array}$ & \multirow[t]{2}{*}{ NA } \\
\hline & $\begin{array}{l}\text { Muscle mass measurement ALM/height }{ }^{2}< \\
7.0 \mathrm{~kg} / \mathrm{m}^{2}(\mathrm{M}),<5.4 \mathrm{~kg} / \mathrm{m}^{2}(\mathrm{~W})(\mathrm{DXA}) \\
\text { ALM/height }{ }^{2}<7.0 \mathrm{~kg} / \mathrm{m}^{2}(\mathrm{M}),<5.7 \mathrm{~kg} / \mathrm{m}^{2}(\mathrm{~W}) \\
\text { (BIA) } \\
\text { Muscle strength measurements Hand grip } \\
\text { strength }<26 \mathrm{~kg}(\mathrm{M}),<18 \mathrm{~kg} \text { (W) } \\
\text { Performance measurement Gait speed } \leq 0.8 \mathrm{~m} / \mathrm{s}\end{array}$ & \\
\hline $\begin{array}{l}\text { Korea Sarcopenic Obesity Study } \\
{[20]}\end{array}$ & $\mathrm{SMI}<7.26 \mathrm{~kg} / \mathrm{m}^{2}(\mathrm{M}),<5.45 \mathrm{~kg} / \mathrm{m}^{2}(\mathrm{~W})(\mathrm{DXA})$ & $\begin{array}{c}\text { Body fat }>27 \%(\mathrm{M}) \\
>38 \%(\mathrm{~W})\end{array}$ \\
\hline
\end{tabular}

SARC-F is a five-question self-reported questionnaire to screen for sarcopenia risk. The question comprises the subjects' perception of his/ her limitations in strength, walking ability, rising from a chair, stair climbing, and experiences with falls [21]. ALM; appendicular lean mass. ASM; appendicular skeletal muscle mass. SPPB; Short physical performance battery. TUG; Timed-Up and Go test. SMI; Skeletal muscle index (total skeletal muscle mass $(\mathrm{kg}) /$ height $\left.(\mathrm{m})^{2}\right)$. VFA; Visceral fat area.

\subsection{Molecular Mechanism of Sarcopenic Obesity}

In sarcopenic obesity, muscle is present as type II muscle fiber atrophy and increased lipid deposition and adipocytes [13,22]. Fast type II muscle fibers switch to slow type I muscle fibers 
resulting in decreased muscle mass and strength [23]. A decrease in motor neurons and collagen deposition is also observed [24].

\subsubsection{Fat Accumulation}

Intramyocellular lipid (IMCL) develops when the inflow of fatty acid exceeds the oxidative capacity of skeletal muscle [25]. IMCL predominantly comprises triacylglycerol; however, other lipid intermediates, such as diacylglycerol (DAG), long-chain acetyl coenzyme A, sterol esters, and sphingolipids, including ceramides, also exist [26,27]. These lipids activate PKC and phosphorylate the serine of insulin receptor substrate-1 (IRS-1), interfering with PI3K activation and blocking GLUT4 translocation [28]. GLUT4 is a membrane transporter that transports glucose from blood into myocytes and its dysfunction results in decreased glucose utilization and increased fatty acid oxidation in the mitochondria. Increased fatty acid inflow leads to an increase in the ATP/ADP ratio in the mitochondria, along with a reduced electron transfer chain. This then results in the inhibition of mitochondrial respiration, increase in ROS formation, myocyte toxicity, and finally, development of sarcopenia [29]. Intermyocellular adipose tissue (IMAT) and IMCL secrete myostatin, CCL2, TNF- $\alpha$, IL-1 $\beta$, and IL-6, thus inducing IR and lipotoxicity, which is discussed in the next section [30].

Peri-muscular adipose tissue (PMAT) is an ectopic fat deposition surrounding muscle. Increased PMAT enhanced nuclear translocation of the FoxO (forkhead box $\mathrm{O}$ ) transcription factors and upregulates Atrogin1 and MuRF1, which leads to proteolysis in muscle tissues. The amount of PMAT is correlated with the severity of muscle atrophy [31].

The perilipin family of proteins (PLIN) is embedded in lipid droplets, and functions as a regulator of skeletal muscle lipid metabolism and mitochondrial oxidation [32,33]. PLIN comprises PLIN1 to PLIN5, and PLIN2 and PLIN 5 are predominantly found in muscle tissue [34,35]. Overexpression of PLIN5 in skeletal muscle increases the gene expression involving fatty acid oxidation mediating PPAR $\alpha$ and PGC1 $\alpha$ [33]. Ablation of PLIN5 results in reduced TAG storage, but increased sphingolipids such as ceramide and sphingomyelin, thus leading to IR in the skeletal muscle [36]. In cultured myocytes, a lipid droplet-associated protein perilipin 2 increases expression of NLRP3 inflammasome, resulting in impaired insulin-stimulated glucose uptake [37].

These results suggest that increased fat accumulation in muscle impairs energy metabolism as well as glucose homeostasis, leading to catabolic status and atrophy of the skeletal muscle.

\subsubsection{Inflammation}

In sarcopenic obesity, adipocytes are accumulated not only in muscle tissue, but also in other organs. Increased adipose tissue secretes proinflammatory cytokines such as TNF- $\alpha$, IL-6, and IL-1, and this promotes infiltration of inflammatory cells, including macrophages. In adipose tissue from lean subjects, approximately $10 \%$ of cells stained positive for macrophages, but in obese subjects, this number increased to up to 50\% [38]. The infiltrated macrophages in muscle tissue present adipocyte-derived antigens and activate antigen-specific $\mathrm{CD} 4^{+} \mathrm{T}$ cells [39]. Macrophages also change the phenotype from M2 to M1, which releases proinflammatory molecules such as TNF- $\alpha$, IL-1 $\beta$, IL-6, and MCP-1/CCL2 [40,41]. These cytokines induce muscle atrophy by increasing apoptosis and upregulating proteosomal decay of filament proteins [42]. Using a proteomics approach, the cellular pathways activating macrophages are associated with sterile inflammation, which is distinct from classical activation by bacterial or viral infection [43,44]. In obesity-induced activation of macrophages, CD38, CD319, and CD274, are derived from the cell surface and only approximately $5 \%$ of the cell surface protein expression patterns overlap [43]. However, macrophages regulate inflammation in adipose tissue, and have autophagic functions whereby they prevent proinflammatory M1 macrophage-polarization by delivering cytoplasmic contents to lysosomes to degrade them and promote homeostasis through an mTOR activation process [44].

Taken together, increased fatty acid uptake and its accumulation in muscle induces inflammation with adipokines, proinflammatory cytokines, and other molecules, resulting in toxic effects on myocytes 
and ultimately sarcopenia. Sarcopenia results in a decreased metabolic rate, low physical activity, and myokine deficiency, which collectively leads to the proinflammatory effect, and exacerbates obesity.

\subsubsection{Sex-Specific Hormone and Growth Hormone Deficiency}

Testosterone is an anabolic hormone that simulates protein synthesis by increasing amino acid utilization, and it also increases androgen receptor expression in skeletal muscle cells [45]. Consequently, testosterone increases muscle mass and insulin-like growth factor-1 (IGF-1) concentration and decreases inflammatory cytokines, such as IL-1 [46]. In obesity, the serum levels of testosterone decrease in response to increased aromatase activity, which converts testosterone to estradiol aromatization, resulting in hypogonadotropic hypogonadism [46]. Hypogonadal status also contributes to sarcopenic obesity by increasing levels of TNF- $\alpha$ and IL-6, which leads to central obesity [11,47].

In menopausal women, decreased levels of estrogen and increased levels of follicle-stimulating hormone and androgen resulted in increased deposition of visceral adipose tissues and decreased fat-free mass, leading to sarcopenic obesity [48].

Growth hormone $(\mathrm{GH})$ is another anabolic hormone that activates multiple signaling cascades, and declines with aging and obesity. Low GH levels reduce IGF1 action by sequentially downregulating the PI3K-AKT/PKB-mTOR pathway, which induces protein synthesis in muscles [49]. The IGF-IR/IR knockout mice showed decreased skeletal muscle mass [50].

In brief, the process of sarcopenia, due specifically to decreased production of sex-specific hormone and growth hormone with aging, is aggravated by obesity.

\section{Sarcopenic Obesity and Insulin Resistance}

Skeletal muscle is the largest major organ for disposal (or reservoir) of postprandial glucose ingestion via an insulin dependent mechanism [11,51]. IR reflects the status of impaired insulin signaling, which consequently results in glucose transport and metabolism process that are closely related to sarcopenic obesity.

\subsection{At Skeletal Muscle}

In the normal physiology of skeletal muscle, insulin binds to the transmembrane insulin receptor, autophosphorylates tyrosine residues in the activation loop, activates IRS-1 and IRS-2, and successively activates PIC3K. PIC3K phosphorylates membrane lipid PIP2, converting it to PIP3. PIP3 binds to Akt, which catalyzes the phosphorylation of proteins, facilitating glycogen synthesis and translocation of GLUT4. GLUT4 moves through the plasma membrane and then acts in a dose-dependent manner. Imported glucose is stored as glycogen or enters the glycolytic pathway, and is either oxidized or released as lactate [52]. Additionally, insulin is involved in the maintenance of muscle mass via the p38MAPK and the mTOR/p70S6 kinase pathway, thus suppressing proteolysis [53-55].

In sarcopenic obesity, the increased lipid metabolites, such as including DAG and ceramides, activate serine/threonine kinases such as PKC, C-Jun NH2-terminal kinase (JNK), and IKK, resulting in the phosphorylation of serine/threonine in the insulin receptor protein and its substrates, resulting in impaired insulin signaling [28,56]. In lipid infusion experiments, DAG content in the muscle increases, and consequently PKC $\theta$ is activated, resulting in limited phosphorylation of IRS- 1 and glucose uptake through GLUT4 [9]. PKC $\theta$ impairs muscle insulin signaling, inhibiting insulin-mediated glucose uptake through GLUT4.

IR correlates with impaired lipid oxidation in the mitochondria [57]. The accumulation of lipids and their metabolites, particularly long chain fatty acids, causes lipotoxicity, and promotes ROS production and ER stress as a result of inflammation, which in turn leads to impaired mitochondrial dysfunction [57]. Mitochondrial dysfunction results in further intracellular fatty acid ambulation, creating a vicious cycle of lipotoxicity [58]. An increase in oxidant compounds activates the stress pathways including IKK, JNK, and p38-MAPK [59]. 
While a report shows that local inflammation induced by muscle MCP-1 overexpression interferes with insulin signaling in muscle [60], the other study does not report a similar observation [61]. The following signaling pathways are currently being examined for sarcopenic obesity and IR.

\subsubsection{IKK/NF-kB Pathway}

The IKK/NF-kB pathway is activated by TNF- $\alpha$, IL-1 $\beta$, and free-fatty acids [62]. IKK-mediated serine phosphorylation of IRS-1 or insulin receptor results in impairment of insulin-induced tyrosine phosphorylation. It results in decreased GLUT4 expression and increased nitric oxide synthase (iNOS) production, leading to IR [63-65].

\subsubsection{MAPK Family}

JNK is a member of the MAPK family and is activated by TNF- $\alpha$, IL-1 $\beta$, free-fatty acids, ER stress, and LTB4 $[66,67]$. JNK causes IR by inducing serine and threonine phosphorylation of IRS and attenuating downstream insulin signaling [68]. Activated p38 MAPK is also involved in muscle IR [69]. Palmitate-induced IR in myocytes shows increase in JNK activity and knockdown of JNK in mice, which shows alleviated IR by enhanced fatty acid utilization and glucose oxidation [70,71].

\subsubsection{JAK/STAT}

IFN- $\gamma$ activates JAK1 and JAK2 inducing STAT1 phosphorylation. IL-6 and palmitate causes STAT3 phosphorylation. It is not fully understood how the JAK-STAT pathway leads to IR in muscle tissues, and controversial results from previous studies have suggested that muscle-specific STAT3 in mice does not alter IR [72,73].

The suppressor of cytokine signaling (SOCS), particularly SOCS1 and SOCS3, are proteins inhibiting inflammatory signaling by blocking JAK activity [74]. This suppressing activity interferes with the crosstalk between the insulin receptor and IRS by inhibiting insulin receptor tyrosine kinase activity and degrading IRS [74,75]. In mice, macrophage-specific ablation of SOCS1 increases systemic inflammation and IR [76], and a loss of function of the cavin-1 binding sites on SOCS3 consequently induces lipodystrophy and IR in mice [77].

\subsubsection{PKCs}

PKC is a family of serine/threonine kinase activated by phospholipase $C$ and hydrolysis of membrane phosphoinositides [78]. PKCs are grouped into three classes, as follows: classical PKCs $(\alpha, \beta 1, \beta 2, \gamma)$, novel PKCs $(\delta, \varepsilon, \eta, \theta)$, and atypical PKCs $(\zeta, \lambda / \iota)[79]$. PKC $\theta$ is predominantly expressed in skeletal muscle and endothelium and is activated by increased DAG content in muscles, via elevated plasma fatty acid infusion in humans [80] or palmitate treatment in myocytes [64]. Similar to IKK and JNK pathways, it induces serine or threonine phosphorylation or IR or IRS-1, resulting in impairment of insulin signaling [80,81].

\subsection{Crosstalk Between Myocyte and Adipocytes}

\subsubsection{IL-6}

IL-6 is a cytokine produced by numerous cell types, such as myocytes, adipocytes, and leukocytes, and it has dual effects in inflammation [82]. As a myokine, IL-6 releases from the skeletal muscle in condition of acute muscle contraction without damage [83]. Acute increment of IL-6 in healthy humans in association with classic signaling, improved insulin sensitivity by enhancing glucose uptake, and increased fatty acid oxidation in myocytes [84]. In the pancreas, IL-6 stimulates insulin secretion by beta cells by upregulating glucagon-like peptide-1 (GLP-1) [85]. It also induces anti-inflammatory cytokines, such as IL-10, and inhibits the feedback of the TNF- $\alpha$ pathway [59].

In contrast, in chronic states such as obesity, IL-6 acts as a pro-inflammatory cytokine via the trans-signaling pathway. A high-fat diet leads to chronically elevated levels of IL-6, which then 
recruits macrophages in the adipose tissue [86]. This results in decreased IGF-1 levels and reduced muscle mass and strength by elevated expression of SOCS3 $[87,88]$. Chronically elevated IL-6 levels increase MAP3K8 expression in adipose tissue, which is a signal transducer that regulates activation of NF-kB and JNK transcription factors and leads to IR [89]. Long-term increment of serum IL-6 levels prospectively predicts unstable atherosclerotic plaques in patients with internal carotid artery stenosis [90]. In older, healthy subjects, progressive strength training reduced serum IL-6 levels compared to that in a control group [91].

Therefore, IL-6 is not only involved in the communication between skeletal muscle and adipose tissue, but also involved in the crosstalk between the pancreas and liver to control glucose metabolism and the cardiovascular system, which, in turn, may control sarcopenia and obesity.

\subsubsection{Irisin}

Irisin is a PPAR $\gamma$-coactivator-1 $\alpha$ (PGC $\alpha$ )-dependent myokine that stimulates browning in subcutaneous adipose tissues and induces increased energy expenditure, which improves obesity and IR through the MAPK and ERK pathways [92,93]. Irisin also stimulates beta-cell survival and glucose-stimulated insulin secretion through the PGA pathway, and inhibits saturated fatty acid-induced apoptosis in pancreatic beta-cells [94]. A low level of irisin in mice with muscle-specific constitutive ROCK1 activation suppresses irisin production in muscles, decreasing browning in adipocytes and leading to impaired insulin sensitivity [95].

In human studies, the level of plasma irisin was positively associated with muscle mass and strength and negatively associated with the fasting glucose level [96]. However, the results on the association between exercise and change in irisin expression are conflicting because of differences among studies, in the exercise regimen programs prescribes, the characteristic of the study populations, and the types of measurement assays used [97-99].

Taken together, irisin has a beneficial effect on metabolic homeostasis, but further investigations are needed to find the role of irisin in sarcopenic obesity and cardiometabolic diseases.

\subsubsection{Adiponectin}

Adiponectin is one of the adipokines that is released from adipocytes, and regulates appetite and energy expenditure. In obesity, the serum level of adiponectin decreases. Thus, it facilitates insulin sensitivity by increasing glucose uptake in skeletal muscle and by stimulating fatty acid oxidation through activation of the 5'-AMP-activated protein kinase (AMPK) signaling pathway [100]. Adiponectin also decreases inflammation by inhibiting TNF- $\alpha$ and IL- $\gamma$ secretion and elevating IL-10 and IL-1 receptor antagonist production from monocytes and macrophages [82]. In contrast, TNF- $\alpha$ impairs adiponectin signaling, mitochondrial biogenesis, and oxidative capacity, resulting in impaired functionality of skeletal muscles [101].

In human studies, resistance and aerobic exercise improved sarcopenic obesity and increased the adiponectin levels in overweight or obese breast cancer survivors [102]. However, there is a controversy about whether adiponectin reflects skeletal muscle improved by exercise or fat accumulation. In overweight or obese postmenopausal women, the adiponectin level increased by $9.5 \%$ in the diet intervention group but by $6.5 \%$ in both diet and exercise groups [103].

In summary, adiponectin is negatively associated with obesity and has a protective effect for inflammation and lipid accumulation in skeletal muscle, but further studies are needed to elucidate its clinical effect, particularly in the subjects with sarcopenic obesity. 


\section{Pathophysiological Link among Cardiometabolic Disease, Sarcopenic Obesity, and Insulin Resistance}

\subsection{Atherosclerosis and Cardiovascular Disease}

Atherogenesis is a complicated process that includes oxidative stress, inflammation, endothelial dysfunction, vascular proliferation, and thrombosis [104]. Atherosclerotic plaque rupture can lead to myocardial infarction and stroke [105]. Hyperinsulinemia due to IR impairs the IRS-1/PI3K/Akt pathway, which causes vasodilation by activating nitric oxide synthase (NOS) and leads to the production of nitric oxide (NO) [106]. This results in impaired vasodilation and endothelial dysfunction, leading to the development of atherosclerosis. In contrast, as the MAPK pathway has normal sensitivity to insulin, hyperinsulinemia activates the MAPK pathway, promoting vascular smooth muscle cell growth and activating inflammatory pathways, such as IkB/NF-kB and JNK [107,108].

In adipocytes, IR by impaired insulin/mTOR2 signaling results in increased MCP1 production, which results in increased circulating MCP1. This activates the proinflammatory M1 macrophages which release cytokines such as TNF- $\alpha$ [109]. When macrophages are under oxidative stress, oxidized lipids such as 7-hydroperoxide proceed to inactivate CYP27A1, reducing ABCA1/G1 expression and ultimately leading to impaired cholesterol efflux to the extracellular apoA-I or HDL [110]. Excessive oxidized LDL cholesterol imported into macrophages leads to the development of foam cells that are deposited beneath the endothelium in arteries, forming atherosclerotic plaques [110].

In a clinical study, patients with sarcopenic obesity had higher carotid intima-media thickness (IMT) and oxidative stress markers compared to sarcopenic non-obese and/or non-sarcopenic patients [111]. Among patients with myocardial infarction, those with visceral obesity had elevated levels of proinflammatory cytokines, such as TNF- $\alpha$, IL-1b, IL-6, IL-8, IL-12, and CRP than those without visceral obesity [112]. A British regional health study reported that older subjects with sarcopenic obesity had the highest cardiovascular mortality [113].

These results suggest that sarcopenic obesity mediated IR accompanies vascular smooth muscle growth and vascular endothelial damage by chronic inflammation and oxidative stress, leading to atherosclerosis and cardiovascular disease [114].

\subsection{Chronic Heart Failure}

Chronic heart failure is the status of a clinical endpoint with decreased pumping function, resulting in impaired organ perfusion usually followed by myocardial infarction or stroke. IR and chronic inflammation are observed in chronic heart failure. Sarcopenic obesity shares these conditions as well.

Hyperinsulinemia, due to IR, activates the renin-angiotensin-aldosterone system (RAS). Increased levels of angiotensin II and following increased aldosterone levels activates the angiotensin receptor 1 and mineralocorticoid receptors, respectively, which stimulates mTOR-S6K1 signaling in heart IR $[115,116]$. The mTOR-S6K1 pathway increases the expression of epithelial sodium channels in the vascular cell membrane and activates serum-and-glucocorticoid-regulated kinase 1, which leads to reduced NO production and increased cardiac stiffness [117]. Moreover, angiotensin II type 1 receptor and mineralocorticoid receptor activate the TGF- $31-S M A D$ pathway, which increases myocardial fibrosis and structural remodeling [118]. Increased RAS also activates sympathetic neurons that contribute to impaired autonomic regulation in heart failure. RAS activity in brain paraventricular nucleus upregulates MAPK signaling and results in sympathetic excitation in rats with heart failure [119].

Inflammation due to sarcopenic obesity results in reduced NO, cyclic guanosine monophosphate (cGMP), and protein kinase G (PKG) activity in cardiomyocytes, leading to LV hypertrophy and stiffness [120]. Activated macrophages release TNF- $\alpha$, IL-1b, IL-6, and TGF- $\beta$, which stimulate myofibroblasts, increase collagen production, and decrease protease inhibitor secretion [121,122]. As a result, the extracellular matrix is degraded by Smad-dependent and/or independent signaling pathways and fibrosis occurs in both cardiac and skeletal muscles [123]. 
Reduced mitochondrial function leads to impaired muscle contractile function and cardiomyocyte death. In rats with heart failure, pro-oxidants such as NADPH oxidase and $\mathrm{XO}$ activity were higher, and antioxidants, such as catalase and superoxide dismutase (SOD), were lower than in corresponding controls [124].

In a clinical study, patients with sarcopenia and/or obesity had a higher risk of co-morbidity and poor prognosis with chronic heart failure [125]. Even in subjects without heart failure, myocardial infarction, and diabetes mellitus, fasting plasma insulin level was positively associated with adverse echocardiographic features, which predispose them to a risk of heart failure [126]. Furthermore, patients with chronic heart failure showed adiponectin resistance in myocardial and skeletal muscle cells through increased oxidative stress [127].

\subsection{Type 2 Diabetes Mellitus}

IR plays a major role in the pathogenesis of type 2 diabetes mellitus [128]. Even though pancreatic beta cell dysfunction is the main pathogenesis of type 2 diabetes mellitus, given that the uptake of postprandial glucose by skeletal muscles is approximately $80-90 \%$, skeletal muscle IR plays a crucial role in the development and progression of diabetes mellitus $[129,130]$.

In a clinical study, patients with sarcopenic obesity with higher BMI and lower hand grip strength had a higher risk of type 2 diabetes mellitus than controls did [131]. We also previously reported that patients with type 2 diabetes mellitus had higher BMI and a low appendicular skeletal mass and skeletal muscle index [132].

\subsection{Metabolic Syndrome}

Metabolic syndrome shares risk factors for type 2 diabetes mellitus and atherosclerotic cardiovascular disease, which tend to namely be abdominal obesity, hyperglycemia, dyslipidemia, and hypertension. Another name for the syndrome is IR syndrome. It is closely associated with IR and obesity, and excess energy intake is usually the underlying cause of the syndrome [133]. Fat accumulation increases oxidative stress due to increased ROS production and NADPH oxidase activation [134]. It causes the dysregulation of adipocytokines, such as adiponectin, PAI-1, IL-6, and MCP-1, leading to metabolic syndrome [134]. IR also activates SREBP-1c and inhibits acetyl-coenzyme A carboxylase, leading to reduced PPAR-a expression and the promotion of large-sized and TG-rich VLDL synthesis and secretion [135].

Most clinical studies have reported that sarcopenic obesity is associated with metabolic syndrome [136-138]. However, in an Australian study assessing older men, sarcopenic obesity was associated with metabolic syndrome; however, obesity itself, rather than the sarcopenia measured by ALM, grip strength, or gait speed was more predictive of metabolic syndrome [139].

\subsection{NAFLD}

IR is the main characteristic of NAFLD and is observed in the liver, skeletal muscle, and adipose tissue in sarcopenic obesity [140]. Sarcopenic obesity seems to impair insulin signaling in hepatocytes, resulting in increased de novo hepatic lipogenesis and inhibited hepatic $\beta$-oxidation [141]. Moreover, obesity accompanies the accumulation of lipids in the liver, thus aggravating insulin resistance in hepatocytes [141]. In genetic mouse models of muscle-specific IR, by deleting the IRTK [142] or GLUT4 [143] genes, hepatic steatosis and adiposity were increased [142].

Chronic inflammation releases cytokines TNF- $\alpha$, IL-6, and CRP in muscle and adipose tissues, aggravating IR and hepatic injury [144]. Decreased adiponectin levels are also noted in advanced hepatic injury [145]. When hepatocyte injury occurs, oxidative stress activates Kupffer cells, which release TNF- $\alpha$ and IL-6, leading to chronic inflammation and liver fibrogenesis progression [146]. Recently, it was reported that NAFLD affects intestinal microbiota, resulting in decreased immune T-cells and increased proinflammatory markers, including TNF- $\alpha$, IL-6, and IFN- $\gamma$ [147]. 
In a longitudinal cohort, subjects with sarcopenia were shown to have a higher risk of NAFLD and increased skeletal muscle index resolute [148]. Several cross-sectional studies have shown an association between sarcopenia and/or obesity and NAFD [144,149]. We have also reported that sarcopenia is independently associated with IR, as measured by HOMA-IR and NAFLD [150].

\section{Conclusions}

Accumulating evidence indicates that cardiometabolic diseases are associated with sarcopenic obesity and IR, and both play pivotal roles in disease development and progression. The clinical definition of sarcopenic obesity has not been unified and each set of diagnostic criteria has different clinical implications. However, the defining phenomena include decreased muscle mass and reduced strength of the muscle irrespective of size, and increased adiposity. Sarcopenic obesity is associated with (i) inflammation cascades that release proinflammatory cytokines, including TNF- $\alpha$, IL-1, and IL-6, and activate M1 macrophages, and (ii) alterations in growth hormone, testosterone, and estradiol. In skeletal muscles, these changes activate several pathways, such as the IKK/NF-kB, JNK, PKC, and JAK/STAT pathways, which result in IR. In sarcopenic obesity accompanied IR, the proposed mechanisms lead to multiple cardiometabolic diseases, including cardiovascular disease, atherosclerosis, chronic heart failure, type 2 diabetes mellitus, metabolic syndrome, and NAFLD. Further studies are needed to clarify the mechanisms contributing to the conflicting molecular and clinical results that are evident between cardiometabolic diseases and sarcopenic obesity with IR. Advancing the understanding of sarcopenic obesity and IR may lead to the emergence of novel therapies to prevent cardiometabolic diseases in aging populations.

Author Contributions: S.-h.H. designed and wrote the manuscript and K.M.C. supervised and revised the manuscript. All authors approved the submitted version of the paper. All authors have read and agreed to the published version of the manuscript.

Funding: Kyung Mook Choi was supported by the Korea University Research Fund (Q1625561).

Conflicts of Interest: The authors declare no conflict of interest.

\section{References}

1. United Nations. World Population Prospects: The 2017 Revision, Key Findings and Advance Tables; United Nations: New York, NY, USA, 2017.

2. Cruz-Jentoft, A.J.; Bahat, G.; Bauer, J.; Boirie, Y.; Bruyere, O.; Cederholm, T.; Cooper, C.; Landi, F.; Rolland, Y.; Sayer, A.A.; et al. Writing Group for the European Working Group on Sarcopenia in Older People (EWGSOP2) and the Extended Group for EWGSOP2. Sarcopenia: Revised European consensus on definition and diagnosis. Age Ageing 2019, 48, 16-31. [CrossRef] [PubMed]

3. Roubenoff, R. Sarcopenic obesity: The confluence of two epidemics. Obes. Res. 2004, 12, 887-888. [CrossRef] [PubMed]

4. Kim, Y.; White, T.; Wijndaele, K.; Sharp, S.J.; Wareham, N.J.; Brage, S. Adiposity and grip strength as long-term predictors of objectively measured physical activity in 93,015 adults: The UK Biobank study. Int. J. Obes. 2017, 41, 1361. [CrossRef] [PubMed]

5. Ma, J.; Hwang, S.J.; McMahon, G.M.; Curhan, G.C.; Mclean, R.R.; Murabito, J.M.; Fox, C.S. Mid-adulthood cardiometabolic risk factor profiles of sarcopenic obesity. Obesity 2016, 24, 526-534. [CrossRef]

6. Scott, D.; Chandrasekara, S.D.; Laslett, L.L.; Cicuttini, F.; Ebeling, P.R.; Jones, G. Associations of sarcopenic obesity and dynapenic obesity with bone mineral density and incident fractures over 5-10 years in community-dwelling older adults. Calcif. Tissue Int. 2016, 99, 30-42. [CrossRef]

7. Zhang, X.; Xie, X.; Dou, Q.; Liu, C.; Zhang, W.; Yang, Y.; Deng, R.; Cheng, A.S. Association of sarcopenic obesity with the risk of all-cause mortality among adults over a broad range of different settings: A updated meta-analysis. BMC Geriatr. 2019, 19, 183. [CrossRef]

8. Benziger, C.P.; Roth, G.A.; Moran, A.E. The global burden of disease study and the preventable burden of NCD. Glob. Heart 2016, 11, 393-397. [CrossRef] 
9. Samuel, V.T.; Shulman, G.I. The pathogenesis of insulin resistance: Integrating signaling pathways and substrate flux. J. Clin. Investig. 2016, 126, 12-22. [CrossRef]

10. Abdul-Ghani, M.A.; DeFronzo, R.A. Pathogenesis of insulin resistance in skeletal muscle. J. Biomed. Biotechnol. 2010, 2010, 476279. [CrossRef]

11. Kalyani, R.R.; Corriere, M.; Ferrucci, L. Age-related and disease-related muscle loss: The effect of diabetes, obesity, and other diseases. Lancet Diabetes Endocrinol. 2014, 2, 819-829. [CrossRef]

12. Yamashita, M.; Kamiya, K.; Matsunaga, A.; Kitamura, T.; Hamazaki, N.; Matsuzawa, R.; Nozaki, K.; Tanaka, S.; Nakamura, T.; Maekawa, E.; et al. Prognostic value of sarcopenic obesity estimated by computed tomography in patients with cardiovascular disease and undergoing surgery. J. Cardiol. 2019, 74, 273-278. [CrossRef] [PubMed]

13. Batsis, J.A.; Villareal, D.T. Sarcopenic obesity in older adults: Aetiology, epidemiology and treatment strategies. Nat. Rev. Endocrinol. 2018, 14, 513-537. [CrossRef] [PubMed]

14. Rolland, Y.; Lauwers-Cances, V.; Cristini, C.; Abellan van Kan, G.; Janssen, I.; Morley, J.E.; Vellas, B. Difficulties with physical function associated with obesity, sarcopenia, and sarcopenic-obesity in community-dwelling elderly women: The EPIDOS (EPIDemiologie de l'OSteoporose) Study. Am. J. Clin. Nutr. 2009, 89, 1895-1900. [CrossRef] [PubMed]

15. Kim, T.N.; Park, M.S.; Lee, E.J.; Chung, H.S.; Yoo, H.J.; Kang, H.J.; Song, W.; Baik, S.H.; Choi, K.M. Comparisons of three different methods for defining sarcopenia: An aspect of cardiometabolic risk. Sci. Rep. 2017, 7, 6491. [CrossRef]

16. Baumgartner, R.N. Body composition in healthy aging. Ann. N. Y. Acad. Sci. 2000, 904, 437-448. [CrossRef]

17. Davison, K.K.; Ford, E.S.; Cogswell, M.E.; Dietz, W.H. Percentage of body fat and body mass index are associated with mobility limitations in people aged 70 and older from NHANES III. J. Am. Geriatr. Soc. 2002, 50, 1802-1809. [CrossRef]

18. Studenski, S.A.; Peters, K.W.; Alley, D.E.; Cawthon, P.M.; McLean, R.R.; Harris, T.B.; Ferrucci, L.; Guralnik, J.M.; Fragala, M.S.; Kenny, A.M.; et al. The FNIH sarcopenia project: Rationale, study description, conference recommendations, and final estimates. J. Gerontol. A Biol. Sci. Med. Sci. 2014, 69, 547-558. [CrossRef]

19. Chen, L.K.; Liu, L.K.; Woo, J.; Assantachai, P.; Auyeung, T.W.; Bahyah, K.S.; Chou, M.Y.; Chen, L.Y.; Hsu, P.S.; Krairit, O.; et al. Sarcopenia in Asia: Consensus report of the Asian Working Group for Sarcopenia. J. Am. Med. Dir. Assoc. 2014, 15, 95-101. [CrossRef]

20. Kim, T.N.; Yang, S.J.; Yoo, H.J.; Lim, K.I.; Kang, H.J.; Song, W.; Seo, J.A.; Kim, S.G.; Kim, N.H.; Baik, S.H.; et al. Prevalence of sarcopenia and sarcopenic obesity in Korean adults: The Korean sarcopenic obesity study. Int. J. Obes. 2009, 33, 885-892. [CrossRef]

21. Malmstrom, T.K.; Miller, D.K.; Simonsick, E.M.; Ferrucci, L.; Morley, J.E. SARC-F: A symptom score to predict persons with sarcopenia at risk for poor functional outcomes. J. Cachexia Sarcopenia Muscle 2016, 7, 28-36. [CrossRef]

22. Nilwik, R.; Snijders, T.; Leenders, M.; Groen, B.B.L.; van Kranenburg, J.; Verdijk, L.B.; van Loon, L.J.C. The decline in skeletal muscle mass with aging is mainly attributed to a reduction in type II muscle fiber size. Exp. Gerontol. 2013, 48, 492-498. [CrossRef] [PubMed]

23. Gannon, J.; Doran, P.; Kirwan, A.; Ohlendieck, K. Drastic increase of myosin light chain MLC-2 in senescent skeletal muscle indicates fast-to-slow fibre transition in sarcopenia of old age. Eur. J. Cell Biol. 2009, 88, 685-700. [CrossRef] [PubMed]

24. Delbono, O. Neural control of aging skeletal muscle. Aging Cell 2003, 2, 21-29. [CrossRef] [PubMed]

25. Gemmink, A.; Goodpaster, B.H.; Schrauwen, P.; Hesselink, M.K.C. Intramyocellular lipid droplets and insulin sensitivity, the human perspective. Biochim. Biophys. Acta Mol. Cell Biol. Lipids 2017, 1862, 1242-1249. [CrossRef]

26. Brøns, C.; Grunnet, L.G. Mechanisms in endocrinology: Skeletal muscle lipotoxicity in insulin resistance and type 2 diabetes: A causal mechanism or an innocent bystander? Eur. J. Endocrinol. 2017, 176, R67-R78. [CrossRef] [PubMed]

27. Pol, A.; Gross, S.P.; Parton, R.G. Review: Biogenesis of the multifunctional lipid droplet: Lipids, proteins, and sites. J. Cell Biol. 2014, 204, 635-646. [CrossRef]

28. Shulman, G.I. Cellular mechanisms of insulin resistance. J. Clin. Investig. 2000, 106, 171-176. [CrossRef]

29. Affourtit, C. Mitochondrial involvement in skeletal muscle insulin resistance: A case of imbalanced bioenergetics. Biochim. Biophys. Acta. 2016, 1857, 1678-1693. [CrossRef] 
30. Rivas, D.A.; McDonald, D.J.; Rice, N.P.; Haran, P.H.; Dolnikowski, G.G.; Fielding, R.A. Diminished anabolic signaling response to insulin induced by intramuscular lipid accumulation is associated with inflammation in aging but not obesity. Am. J. Physiol. Regul. Integr. Comp. Physiol. 2016, 310, R561-R569. [CrossRef]

31. Zhu, S.; Tian, Z.; Torigoe, D.; Zhao, J.; Xie, P.; Sugizaki, T.; Sato, M.; Horiguchi, H.; Terada, K.; Kadomatsu, T. Aging-and obesity-related peri-muscular adipose tissue accelerates muscle atrophy. PLOS ONE 2019, 14, e0221366. [CrossRef]

32. Peters, S.J.; Samjoo, I.A.; Devries, M.C.; Stevic, I.; Robertshaw, H.A.; Tarnopolsky, M.A. Perilipin family (PLIN) proteins in human skeletal muscle: The effect of sex, obesity, and endurance training. Appl. Physiol. Nutr. Metab. 2012, 37, 724-735. [CrossRef] [PubMed]

33. Bosma, M.; Sparks, L.M.; Hooiveld, G.J.; Jorgensen, J.A.; Houten, S.M.; Schrauwen, P.; Kersten, S.; Hesselink, M.K. Overexpression of PLIN5 in skeletal muscle promotes oxidative gene expression and intramyocellular lipid content without compromising insulin sensitivity. Biochim. Biophys. Acta 2013, 1831, 844-852. [CrossRef] [PubMed]

34. Harris, L.A.; Skinner, J.R.; Shew, T.M.; Pietka, T.A.; Abumrad, N.A.; Wolins, N.E. Perilipin 5-Driven Lipid Droplet Accumulation in Skeletal Muscle Stimulates the Expression of Fibroblast Growth Factor 21. Diabetes 2015, 64, 2757-2768. [CrossRef] [PubMed]

35. Conte, M.; Vasuri, F.; Bertaggia, E.; Armani, A.; Santoro, A.; Bellavista, E.; Degiovanni, A.; D'Errico-Grigioni, A.; Trisolino, G.; Capri, M.; et al. Differential expression of perilipin 2 and 5 in human skeletal muscle during aging and their association with atrophy-related genes. Biogerontology 2015, 16, 329-340. [CrossRef] [PubMed]

36. Bosma, M. Lipid droplet dynamics in skeletal muscle. Exp. Cell Res. 2016, 340, 180-186. [CrossRef] [PubMed]

37. Cho, K.A.; Kang, P.B. PLIN2 inhibits insulin-induced glucose uptake in myoblasts through the activation of the NLRP3 inflammasome. Int. J. Mol. Med. 2015, 36, 839-844. [CrossRef]

38. Weisberg, S.P.; McCann, D.; Desai, M.; Rosenbaum, M.; Leibel, R.L.; Ferrante, A.W. Obesity is associated with macrophage accumulation in adipose tissue. J. Clin. Investig. 2003, 112, 1796-1808. [CrossRef]

39. Morris, D.L.; Cho, K.W.; DelProposto, J.L.; Oatmen, K.E.; Geletka, L.M.; Martinez-Santibanez, G.; Singer, K.; Lumeng, C.N. Adipose tissue macrophages function as antigen-presenting cells and regulate adipose tissue CD4+ T cells in mice. Diabetes 2013, 62, 2762-2772. [CrossRef]

40. Bing, C. Is interleukin-1 $\beta$ a culprit in macrophage-adipocyte crosstalk in obesity? Adipocyte 2015, 4, 149-152. [CrossRef]

41. Castoldi, A.; Naffah de Souza, C.; Câmara, N.O.S.; Moraes-Vieira, P.M. The macrophage switch in obesity development. Front. Immunol. 2016, 6, 637. [CrossRef]

42. Kob, R.; Bollheimer, L.C.; Bertsch, T.; Fellner, C.; Djukic, M.; Sieber, C.C.; Fischer, B.E. Sarcopenic obesity: Molecular clues to a better understanding of its pathogenesis? Biogerontology 2015, 16, 15-29. [CrossRef]

43. Kratz, M.; Coats, B.R.; Hisert, K.B.; Hagman, D.; Mutskov, V.; Peris, E.; Schoenfelt, K.Q.; Kuzma, J.N.; Larson, I.; Billing, P.S. Metabolic dysfunction drives a mechanistically distinct proinflammatory phenotype in adipose tissue macrophages. Cell Metab. 2014, 20, 614-625. [CrossRef]

44. Fitzgibbons, T.P.; Czech, M.P. Emerging evidence for beneficial macrophage functions in atherosclerosis and obesity-induced insulin resistance. J. Mol. Med. 2016, 94, 267-275. [CrossRef]

45. Kadi, F. Cellular and molecular mechanisms responsible for the action of testosterone on human skeletal muscle. A basis for illegal performance enhancement. Br. J. Pharmacol. 2008, 154, 522-528. [CrossRef]

46. Nettleship, J.; Pugh, P.; Channer, K.; Jones, T.; Jones, R. Inverse relationship between serum levels of interleukin- $1 \beta$ and testosterone in men with stable coronary artery disease. Horm. Metab. Res. 2007, 39, 366-371. [CrossRef]

47. Mudali, S.; Dobs, A.S. Effects of testosterone on body composition of the aging male. Mech. Ageing Dev. 2004, 125, 297-304. [CrossRef] [PubMed]

48. Abdulnour, J.; Doucet, E.; Brochu, M.; Lavoie, J.M.; Strychar, I.; Rabasa-Lhoret, R.; Prud'homme, D. The effect of the menopausal transition on body composition and cardiometabolic risk factors: A Montreal-Ottawa New Emerging Team group study. Menopause 2012, 19, 760-767. [CrossRef] [PubMed]

49. Egerman, M.A.; Glass, D.J. Signaling pathways controlling skeletal muscle mass. Crit. Rev. Biochem. Mol. Biol. 2014, 49, 59-68. [CrossRef] [PubMed] 
50. O'Neill, B.T.; Lauritzen, H.P.; Hirshman, M.F.; Smyth, G.; Goodyear, L.J.; Kahn, C.R. Differential role of insulin/IGF-1 receptor signaling in muscle growth and glucose homeostasis. Cell Rep. 2015, 11, 1220-1235. [CrossRef] [PubMed]

51. Kelly, D.; Mitrakou, A.; Marsh, H.; Schwenk, F.; Benn, J.; Sonnenberg, G.; Archangeli, M.; Aoki, T.; Sorensen, J.; Berger, M.; et al. Skeletal muscle glycolysis, oxidation, and storage of an oral glucose load. J. Clin. Investig. 1988, 81, 1563-1571. [CrossRef] [PubMed]

52. Groop, L.C.; Bonadonna, R.C.; DelPrato, S.; Ratheiser, K.; Zyck, K.; Ferrannini, E.; DeFronzo, R.A. Glucose and free fatty acid metabolism in non-insulin-dependent diabetes mellitus. Evidence for multiple sites of insulin resistance. J. Clin. Investig. 1989, 84, 205-213. [CrossRef] [PubMed]

53. Kimball, S.R.; Horetsky, R.L.; Jefferson, L.S. Signal transduction pathways involved in the regulation of protein synthesis by insulin in L6 myoblasts. Am. J. Physiol. Cell Physiol. 1998, 274, C221-C228. [CrossRef] [PubMed]

54. Guillet, C.; Prod'homme, M.; Balage, M.; Gachon, P.; Giraudet, C.; Morin, L.; Grizard, J.; Boirie, Y. Impaired anabolic response of muscle protein synthesis is associated with S6K1 dysregulation in elderly humans. FASEB J. 2004, 18, 1586-1587. [CrossRef] [PubMed]

55. Fujita, S.; Rasmussen, B.B.; Cadenas, J.G.; Drummond, M.J.; Glynn, E.L.; Sattler, F.R.; Volpi, E. Aerobic exercise overcomes the age-related insulin resistance of muscle protein metabolism by improving endothelial function and Akt/mammalian target of rapamycin signaling. Diabetes 2007, 56, 1615-1622. [CrossRef]

56. Boura-Halfon, S.; Zick, Y. Phosphorylation of IRS proteins, insulin action, and insulin resistance. Am. J. Physiol. Endocrinol. Metab. 2009, 296, E581-E591. [CrossRef]

57. Hafizi Abu Bakar, M.; Kian Kai, C.; Wan Hassan, W.N.; Sarmidi, M.R.; Yaakob, H.; Zaman Huri, H. Mitochondrial dysfunction as a central event for mechanisms underlying insulin resistance: The roles of long chain fatty acids. Diabetes Metab. Res. Rev. 2015, 31, 453-475. [CrossRef]

58. Stinkens, R.; Goossens, G.H.; Jocken, J.W.; Blaak, E.E. Targeting fatty acid metabolism to improve glucose metabolism. Obes. Rev. 2015, 16, 715-757. [CrossRef]

59. Kalinkovich, A.; Livshits, G. Sarcopenic obesity or obese sarcopenia: A cross talk between age-associated adipose tissue and skeletal muscle inflammation as a main mechanism of the pathogenesis. Ageing Res. Rev. 2017, 35, 200-221. [CrossRef]

60. Patsouris, D.; Cao, J.-J.; Vial, G.; Bravard, A.; Lefai, E.; Durand, A.; Durand, C.; Chauvin, M.-A.; Laugerette, F.; Debard, $\mathrm{C}$. Insulin resistance is associated with MCP1-mediated macrophage accumulation in skeletal muscle in mice and humans. PLoS ONE 2014, 9, e110653. [CrossRef]

61. Evers-van Gogh, I.J.; Oteng, A.-B.; Alex, S.; Hamers, N.; Catoire, M.; Stienstra, R.; Kalkhoven, E.; Kersten, S. Muscle-specific inflammation induced by MCP-1 overexpression does not affect whole-body insulin sensitivity in mice. Diabetologia 2016, 59, 624-633. [CrossRef]

62. Wu, H.; Ballantyne, C.M. Skeletal muscle inflammation and insulin resistance in obesity. J. Clin. Investig. 2017, 127, 43-54. [CrossRef]

63. Lackey, D.E.; Olefsky, J.M. Regulation of metabolism by the innate immune system. Nat. Rev. Endocrinol. 2016, 12, 15. [CrossRef] [PubMed]

64. Jové, M.; Planavila, A.; Sánchez, R.M.; Merlos, M.; Laguna, J.C.; Vázquez-Carrera, M. Palmitate induces tumor necrosis factor- $\alpha$ expression in $\mathrm{C} 2 \mathrm{C} 12$ skeletal muscle cells by a mechanism involving protein kinase $\mathrm{C}$ and nuclear factor- $\mathrm{\kappa B}$ activation. Endocrinology 2006, 147, 552-561. [CrossRef] [PubMed]

65. Gao, Z.; Hwang, D.; Bataille, F.; Lefevre, M.; York, D.; Quon, M.J.; Ye, J. Serine phosphorylation of insulin receptor substrate 1 by inhibitor $\mathrm{kB}$ kinase complex. J. Biol. Chem. 2002, 277, 48115-48121. [CrossRef] [PubMed]

66. Henstridge, D.C.; Bruce, C.R.; Pang, C.P.; Lancaster, G.I.; Allen, T.L.; Estevez, E.; Gardner, T.; Weir, J.M.; Meikle, P.J.; Lam, K.S.L.; et al. Skeletal muscle-specific overproduction of constitutively activated c-Jun N-terminal kinase (JNK) induces insulin resistance in mice. Diabetologia 2012, 55, 2769-2778. [CrossRef] [PubMed]

67. Li, P.; Oh, D.Y.; Bandyopadhyay, G.; Lagakos, W.S.; Talukdar, S.; Osborn, O.; Johnson, A.; Chung, H.; Maris, M.; Ofrecio, J.M.; et al. LTB4 promotes insulin resistance in obese mice by acting on macrophages, hepatocytes and myocytes. Nat. Med. 2015, 21, 239-247. [CrossRef] [PubMed]

68. Sabio, G.; Davis, R.J. cJun NH2-terminal kinase 1 (JNK1): Roles in metabolic regulation of insulin resistance. Trends Biochem. Sci. 2010, 35, 490-496. [CrossRef] 
69. Talbot, N.A.; Wheeler-Jones, C.P.; Cleasby, M.E. Palmitoleic acid prevents palmitic acid-induced macrophage activation and consequent p38 MAPK-mediated skeletal muscle insulin resistance. Mol. Cell. Endocrinol. 2014, 393, 129-142. [CrossRef]

70. Senn, J.J. Toll-like receptor-2 is essential for the development of palmitate-induced insulin resistance in myotubes. J. Biol. Chem. 2010, 285, 14842. [CrossRef]

71. Vijayvargia, R.; Mann, K.; Weiss, H.R.; Pownall, H.J.; Ruan, H. JNK deficiency enhances fatty acid utilization and diverts glucose from oxidation to glycogen storage in cultured myotubes. Obesity 2010, 18, 1701-1709. [CrossRef]

72. Mashili, F.; Chibalin, A.V.; Krook, A.; Zierath, J.R. Constitutive STAT3 phosphorylation contributes to skeletal muscle insulin resistance in type 2 diabetes. Diabetes 2013, 62, 457-465. [CrossRef] [PubMed]

73. White, A.T.; Schenk, S. Knockout of STAT3 in skeletal muscle does not enhance insulin action. Diabetologia 2013, 56, S250.

74. Tanti, J.-F.; Ceppo, F.; Jager, J.; Berthou, F. Implication of inflammatory signaling pathways in obesity-induced insulin resistance. Front. Endocrinol. 2013, 3, 181. [CrossRef] [PubMed]

75. Ueki, K.; Kondo, T.; Kahn, C.R. Suppressor of cytokine signaling 1 (SOCS-1) and SOCS-3 cause insulin resistance through inhibition of tyrosine phosphorylation of insulin receptor substrate proteins by discrete mechanisms. Mol. Cell. Biol. 2004, 24, 5434-5446. [CrossRef] [PubMed]

76. Sachithanandan, N.; Graham, K.L.; Galic, S.; Honeyman, J.E.; Fynch, S.L.; Hewitt, K.A.; Steinberg, G.R.; Kay, T.W. Macrophage deletion of SOCS1 increases sensitivity to LPS and palmitic acid and results in systemic inflammation and hepatic insulin resistance. Diabetes 2011, 60, 2023-2031. [CrossRef] [PubMed]

77. Williams, J.J.L.; Alotaiq, N.; Mullen, W.; Burchmore, R.; Liu, L.; Baillie, G.S.; Schaper, F.; Pilch, P.F.; Palmer, T.M. Interaction of suppressor of cytokine signalling 3 with cavin-1 links SOCS3 function and cavin-1 stability. Nat. Commun. 2018, 9, 168. [CrossRef]

78. Dempsey, E.C.; Newton, A.C.; Mochly-Rosen, D.; Fields, A.P.; Reyland, M.E.; Insel, P.A.; Messing, R.O. Protein kinase $\mathrm{C}$ isozymes and the regulation of diverse cell responses. Am. J. Physiol. Lung Cell Mol. Physiol. 2000, 279, L429-L438. [CrossRef]

79. Mellor, H.; Parker, P.J. The extended protein kinase C superfamily. Biochem. J. 1998, 332, 281-292. [CrossRef]

80. Szendroedi, J.; Yoshimura, T.; Phielix, E.; Koliaki, C.; Marcucci, M.; Zhang, D.; Jelenik, T.; Müller, J.; Herder, C.; Nowotny, P. Role of diacylglycerol activation of PKC $\theta$ in lipid-induced muscle insulin resistance in humans. Proc. Natl. Acad. Sci. USA 2014, 111, 9597-9602. [CrossRef]

81. Kim, J.K.; Fillmore, J.J.; Sunshine, M.J.; Albrecht, B.; Higashimori, T.; Kim, D.-W.; Liu, Z.-X.; Soos, T.J.; Cline, G.W.; O’Brien, W.R. PKC- $\theta$ knockout mice are protected from fat-induced insulin resistance. J. Clin. Investig. 2004, 114, 823-827. [CrossRef]

82. Chung, H.S.; Choi, K.M. Adipokines and myokines: A pivotal role in metabolic and cardiovascular disorders. Curr. Med. Chem. 2018, 25, 2401-2415. [CrossRef] [PubMed]

83. Fischer, C.P.; Plomgaard, P.; Hansen, A.K.; Pilegaard, H.; Saltin, B.; Pedersen, B.K. Endurance training reduces the contraction-induced interleukin-6 mRNA expression in human skeletal muscle. Am. J. Physiol. Endocrinol. Metab. 2004, 287, E1189-E1194. [CrossRef] [PubMed]

84. Wolsk, E.; Mygind, H.; Grondahl, T.S.; Pedersen, B.K.; van Hall, G. IL-6 selectively stimulates fat metabolism in human skeletal muscle. Am. J. Physiol. Endocrinol. Metab. 2010, 299, E832-E840. [CrossRef] [PubMed]

85. Ellingsgaard, H.; Hauselmann, I.; Schuler, B.; Habib, A.M.; Baggio, L.L.; Meier, D.T.; Eppler, E.; Bouzakri, K.; Wueest, S.; Muller, Y.D.; et al. Interleukin-6 enhances insulin secretion by increasing glucagon-like peptide-1 secretion from L cells and alpha cells. Nat. Med. 2011, 17, 1481-1489. [CrossRef] [PubMed]

86. Kraakman, M.J.; Kammoun, H.L.; Allen, T.L.; Deswaerte, V.; Henstridge, D.C.; Estevez, E.; Matthews, V.B.; Neill, B.; White, D.A.; Murphy, A.J. Blocking IL-6 trans-signaling prevents high-fat diet-induced adipose tissue macrophage recruitment but does not improve insulin resistance. Cell Metab. 2015, 21, 403-416. [CrossRef]

87. Langkilde, A.; Petersen, J.; Henriksen, J.H.; Jensen, F.K.; Gerstoft, J.; Eugen-Olsen, J.; Andersen, O. Leptin, IL-6, and suPAR reflect distinct inflammatory changes associated with adiposity, lipodystrophy and low muscle mass in HIV-infected patients and controls. Immun. Ageing 2015, 12, 9. [CrossRef]

88. McKay, B.R.; Ogborn, D.I.; Baker, J.M.; Toth, K.G.; Tarnopolsky, M.A.; Parise, G. Elevated SOCS3 and altered IL-6 signaling is associated with age-related human muscle stem cell dysfunction. Am. J. Physiol. Cell Physiol. 2013, 304, C717-C728. [CrossRef] 
89. Ballak, D.B.; van Essen, P.; van Diepen, J.A.; Jansen, H.; Hijmans, A.; Matsuguchi, T.; Sparrer, H.; Tack, C.J.; Netea, M.G.; Joosten, L.A.; et al. MAP3K8 (TPL2/COT) affects obesity-induced adipose tissue inflammation without systemic effects in humans and in mice. PLoS ONE 2014, 9, e89615. [CrossRef]

90. Puz, P.; Lasek-Bal, A. Repeated measurements of serum concentrations of TNF-alpha, interleukin- 6 and interleukin-10 in the evaluation of internal carotid artery stenosis progression. Atherosclerosis 2017, 263, 97-103. [CrossRef]

91. Forti, L.N.; Njemini, R.; Beyer, I.; Eelbode, E.; Meeusen, R.; Mets, T.; Bautmans, I. Strength training reduces circulating interleukin-6 but not brain-derived neurotrophic factor in community-dwelling elderly individuals. Age 2014, 36, 9704. [CrossRef]

92. Boström, P.; Wu, J.; Jedrychowski, M.P.; Korde, A.; Ye, L.; Lo, J.C.; Rasbach, K.A.; Boström, E.A.; Choi, J.H.; Long, J.Z. A PGC1- $\alpha$-dependent myokine that drives brown-fat-like development of white fat and thermogenesis. Nature 2012, 481, 463. [CrossRef] [PubMed]

93. Zhang, Y.; Li, R.; Meng, Y.; Li, S.W.; Donelan, W.; Zhao, Y.; Qi, L.; Zhang, M.X.; Wang, X.L.; Cui, T.X.; et al. Irisin Stimulates Browning of White Adipocytes Through Mitogen-Activated Protein Kinase p38 MAP Kinase and ERK MAP Kinase Signaling. Diabetes 2014, 63, 514-525. [CrossRef] [PubMed]

94. Natalicchio, A.; Marrano, N.; Biondi, G.; Spagnuolo, R.; Labarbuta, R.; Porreca, I.; Cignarelli, A.; Bugliani, M.; Marchetti, P.; Perrini, S. The myokine irisin is released in response to saturated fatty acids and promotes pancreatic $\beta$-cell survival and insulin secretion. Diabetes 2017, 66, 2849-2856. [CrossRef]

95. Zhou, X.; Li, R.; Liu, X.; Wang, L.; Hui, P.; Chan, L.; Saha, P.K.; Hu, Z. ROCK1 reduces mitochondrial content and irisin production in muscle suppressing adipocyte browning and impairing insulin sensitivity. Sci. Rep. 2016, 6, 29669. [CrossRef] [PubMed]

96. Kurdiova, T.; Balaz, M.; Vician, M.; Maderova, D.; Vlcek, M.; Valkovic, L.; Srbecky, M.; Imrich, R.; Kyselovicova, O.; Belan, V.; et al. Effects of obesity, diabetes and exercise on Fndc5 gene expression and irisin release in human skeletal muscle and adipose tissue: In vivo and in vitro studies. J. Physiol. 2014, 592, 1091-1107. [CrossRef]

97. Tsuchiya, Y.; Ando, D.; Takamatsu, K.; Goto, K. Resistance exercise induces a greater irisin response than endurance exercise. Metab. Clin. Exp. 2015, 64, 1042-1050. [CrossRef] [PubMed]

98. Norheim, F.; Langleite, T.M.; Hjorth, M.; Holen, T.; Kielland, A.; Stadheim, H.K.; Gulseth, H.L.; Birkeland, K.I.; Jensen, J.; Drevon, C.A. The effects of acute and chronic exercise on PGC-1alpha, irisin and browning of subcutaneous adipose tissue in humans. FEBS J. 2014, 281, 739-749. [CrossRef]

99. Choi, K.M.; Hwang, S.Y.; Han, K.; Chung, H.S.; Kim, N.H.; Yoo, H.J.; Seo, J.-A.; Kim, S.G.; Kim, N.H.; Baik, S.H. Interleukin-15 and irisin serum concentrations are not related to cardiometabolic risk factors in patients with type 2 diabetes from Korea and Germany. Acta Diabetol. 2019, 1-4. [CrossRef]

100. Yamauchi, T.; Kamon, J.; Minokoshi, Y.; Ito, Y.; Waki, H.; Uchida, S.; Yamashita, S.; Noda, M.; Kita, S.; Ueki, K.; et al. Adiponectin stimulates glucose utilization and fatty-acid oxidation by activating AMP-activated protein kinase. Nat. Med. 2002, 8, 1288-1295. [CrossRef]

101. Sente, T.; Van Berendoncks, A.M.; Fransen, E.; Vrints, C.J.; Hoymans, V.Y. Tumor necrosis factor- $\alpha$ impairs adiponectin signalling, mitochondrial biogenesis, and myogenesis in primary human myotubes cultures. Am. J. Physiol. Heart Circ. Physiol. 2016, 310, H1164-H1175. [CrossRef]

102. Dieli-Conwright, C.M.; Courneya, K.S.; Demark-Wahnefried, W.; Sami, N.; Lee, K.; Buchanan, T.A.; Spicer, D.V.; Tripathy, D.; Bernstein, L.; Mortimer, J.E. Effects of Aerobic and Resistance Exercise on Metabolic Syndrome, Sarcopenic Obesity, and Circulating Biomarkers in Overweight or Obese Survivors of Breast Cancer: A Randomized Controlled Trial. J. Clin. Oncol. Off. J. Am. Soc. Clin. Oncol. 2018, 36, 875-883. [CrossRef] [PubMed]

103. Abbenhardt, C.; McTiernan, A.; Alfano, C.M.; Wener, M.H.; Campbell, K.L.; Duggan, C.; Foster-Schubert, K.E.; Kong, A.; Toriola, A.T.; Potter, J.D.; et al. Effects of individual and combined dietary weight loss and exercise interventions in postmenopausal women on adiponectin and leptin levels. J. Intern. Med. 2013, 274, 163-175. [CrossRef] [PubMed]

104. Hansson, G.K. Inflammation, atherosclerosis, and coronary artery disease. N. Engl. J. Med. 2005, 352, 1685-1695. [CrossRef] [PubMed]

105. Grootaert, M.O.; da Costa Martins, P.A.; Bitsch, N.; Pintelon, I.; De Meyer, G.R.; Martinet, W.; Schrijvers, D.M. Defective autophagy in vascular smooth muscle cells accelerates senescence and promotes neointima formation and atherogenesis. Autophagy 2015, 11, 2014-2032. [CrossRef] 
106. Zeng, G.; Nystrom, F.H.; Ravichandran, L.V.; Cong, L.-N.; Kirby, M.; Mostowski, H.; Quon, M.J. Roles for insulin receptor, PI3-kinase, and Akt in insulin-signaling pathways related to production of nitric oxide in human vascular endothelial cells. Circulation 2000, 101, 1539-1545. [CrossRef]

107. Cusi, K.; Maezono, K.; Osman, A.; Pendergrass, M.; Patti, M.E.; Pratipanawatr, T.; DeFronzo, R.A.; Kahn, C.R.; Mandarino, L.J. Insulin resistance differentially affects the PI 3-kinase-and MAP kinase-mediated signaling in human muscle. J. Clin. Investig. 2000, 105, 311-320. [CrossRef]

108. Di Pino, A.; DeFronzo, R.A. Insulin Resistance and Atherosclerosis: Implications for Insulin-Sensitizing Agents. Endocr. Rev. 2019, 40, 1447-1467. [CrossRef]

109. Shimobayashi, M.; Albert, V.; Woelnerhanssen, B.; Frei, I.C.; Weissenberger, D.; Meyer-Gerspach, A.C.; Clement, N.; Moes, S.; Colombi, M.; Meier, J.A. Insulin resistance causes inflammation in adipose tissue. J. Clin. Investig. 2018, 128, 1538-1550. [CrossRef]

110. Korytowski, W.; Wawak, K.; Pabisz, P.; Schmitt, J.C.; Chadwick, A.C.; Sahoo, D.; Girotti, A.W. Impairment of macrophage cholesterol efflux by cholesterol hydroperoxide trafficking: Implications for atherogenesis under oxidative stress. Arterioscler. Thromb. Vasc. Biol. 2015, 35, 2104-2113. [CrossRef]

111. Bellanti, F.; Romano, A.D.; Buglio, A.L.; Castriotta, V.; Guglielmi, G.; Greco, A.; Serviddio, G.; Vendemiale, G. Oxidative stress is increased in sarcopenia and associated with cardiovascular disease risk in sarcopenic obesity. Maturitas 2018, 109, 6-12. [CrossRef]

112. Gruzdeva, O.; Uchasova, E.; Dyleva, Y.; Akbasheva, O.; Matveeva, V.; Karetnikova, V.; Kokov, A.; Barbarash, O. Relationship key factor of inflammation and the development of complications in the late period of myocardial infarction in patients with visceral obesity. BMC Cardiovasc. Disord. 2017, 17, 36. [CrossRef] [PubMed]

113. Atkins, J.L.; Whincup, P.H.; Morris, R.W.; Lennon, L.T.; Papacosta, O.; Wannamethee, S.G. Sarcopenic obesity and risk of cardiovascular disease and mortality: A population-based cohort study of older men. J. Am. Geriatr. Soc. 2014, 62, 253-260. [CrossRef] [PubMed]

114. Kim, T.N.; Choi, K.M. The implications of sarcopenia and sarcopenic obesity on cardiometabolic disease. J. Cell Biochem. 2015, 116, 1171-1178. [CrossRef] [PubMed]

115. Favre, G.A.; Esnault, V.L.; Van Obberghen, E. Modulation of glucose metabolism by the renin-angiotensin-aldosterone system. Am. J. Physiol. Endocrinol. Metab. 2015, 308, E435-E449. [CrossRef] [PubMed]

116. Jia, G.; Aroor, A.R.; Martinez-Lemus, L.A.; Sowers, J.R. Overnutrition, mTOR signaling, and cardiovascular diseases. Am. J. Physiol. Regul. Integr. Comp. Physiol. 2014, 307, R1198-R1206. [CrossRef] [PubMed]

117. Pitt, B. Mineralocorticoid receptor antagonists for the treatment of hypertension and the metabolic syndrome. Hypertension 2015, 65, 41-42. [CrossRef] [PubMed]

118. Harper, S.C.; Brack, A.; MacDonnell, S.; Franti, M.; Olwin, B.B.; Bailey, B.A.; Rudnicki, M.A.; Houser, S.R. Insulin Signaling and Heart Failure. Circ. Res. 2016, 118, 1143-1150. [CrossRef]

119. Yu, Y.; Wei, S.G.; Zhang, Z.H.; Weiss, R.M.; Felder, R.B. ERK1/2 MAPK signaling in hypothalamic paraventricular nucleus contributes to sympathetic excitation in rats with heart failure after myocardial infarction. Am. J. Physiol. Heart Circ. Physiol. 2016, 310, H732-H739. [CrossRef]

120. Paulus, W.J.; Tschöpe, C. A novel paradigm for heart failure with preserved ejection fraction: Comorbidities drive myocardial dysfunction and remodeling through coronary microvascular endothelial inflammation. J. Am. Coll. Cardiol. 2013, 62, 263-271. [CrossRef]

121. Nishida, K.; Otsu, K. Inflammation and metabolic cardiomyopathy. Cardiovasc. Res. 2017, 113, 389-398. [CrossRef]

122. Kitessa, S.M.; Abeywardena, M.Y. Lipid-induced insulin resistance in skeletal muscle: The chase for the culprit goes from total intramuscular fat to lipid intermediates, and finally to species of lipid intermediates. Nutrients 2016, 8, 466. [CrossRef]

123. Michalska-Kasiczak, M.; Bielecka-Dabrowa, A.; von Haehling, S.; Anker, S.D.; Rysz, J.; Banach, M. Biomarkers, myocardial fibrosis and co-morbidities in heart failure with preserved ejection fraction: An overview. Arch. Med. Sci. AMS 2018, 14, 890. [CrossRef] [PubMed]

124. Bowen, T.S.; Rolim, N.P.; Fischer, T.; Bækkerud, F.H.; Medeiros, A.; Werner, S.; Brønstad, E.; Rognmo, O.; Mangner, N.; Linke, A. Heart failure with preserved ejection fraction induces molecular, mitochondrial, histological, and functional alterations in rat respiratory and limb skeletal muscle. Eur. J. Heart Fail. 2015, 17, 263-272. [CrossRef] [PubMed] 
125. Suzuki, T.; Palus, S.; Springer, J. Skeletal muscle wasting in chronic heart failure. ESC Heart Fail. 2018, 5, 1099-1107. [CrossRef] [PubMed]

126. Banerjee, D.; Biggs, M.L.; Mercer, L.; Mukamal, K.; Kaplan, R.; Barzilay, J.; Kuller, L.; Kizer, J.R.; Djousse, L.; Tracy, R. Insulin resistance and risk of incident heart failure: Cardiovascular Health Study. Circ. Heart Fail. 2013, 6, 364-370. [CrossRef]

127. Sente, T.; Van Berendoncks, A.M.; Hoymans, V.Y.; Vrints, C.J. Adiponectin resistance in skeletal muscle: Pathophysiological implications in chronic heart failure. J. Cachexia Sarcopenia Muscle 2016, 7, 261-274. [CrossRef] [PubMed]

128. Rothman, D.L.; Magnusson, I.; Cline, G.; Gerard, D.; Kahn, C.R.; Shulman, R.G.; Shulman, G.I. Decreased Muscle Glucose-Transport Phosphorylation Is an Early Defect in the Pathogenesis of Non-Insulin-Dependent Diabetes-Mellitus. Proc. Natl. Acad. Sci. USA 1995, 92, 983-987. [CrossRef] [PubMed]

129. Ferrannini, E.; Simonson, D.C.; Katz, L.D.; Reichard, G., Jr.; Bevilacqua, S.; Barrett, E.J.; Olsson, M.; DeFronzo, R.A. The disposal of an oral glucose load in patients with non-insulin-dependent diabetes. Metabolism 1988, 37, 79-85. [CrossRef]

130. DeFronzo, R.A.; Tripathy, D. Skeletal Muscle Insulin Resistance Is the Primary Defect in Type 2 Diabetes. Diabetes Care 2009, 32, S157-S163. [CrossRef]

131. Cuthbertson, D.J.; Bell, J.A.; Ng, S.Y.; Kemp, G.J.; Kivimaki, M.; Hamer, M. Dynapenic obesity and the risk of incident Type 2 diabetes: The English Longitudinal Study of Ageing. Diabet. Med. 2016, 33, 1052-1059. [CrossRef]

132. Kim, T.N.; Park, M.S.; Yang, S.J.; Yoo, H.J.; Kang, H.J.; Song, W.; Seo, J.A.; Kim, S.G.; Kim, N.H.; Baik, S.H.; et al. Prevalence and determinant factors of sarcopenia in patients with type 2 diabetes: The Korean Sarcopenic Obesity Study (KSOS). Diabetes Care 2010, 33, 1497-1499. [CrossRef] [PubMed]

133. Grundy, S.M. Metabolic syndrome update. Trends Cardiovasc. Med. 2016, 26, 364-373. [CrossRef] [PubMed]

134. Furukawa, S.; Fujita, T.; Shimabukuro, M.; Iwaki, M.; Yamada, Y.; Nakajima, Y.; Nakayama, O.; Makishima, M.; Matsuda, M.; Shimomura, I. Increased oxidative stress in obesity and its impact on metabolic syndrome. J. Clin. Investig. 2004, 114, 1752-1761. [CrossRef] [PubMed]

135. Lucero, D.; Miksztowicz, V.; Macri, V.; López, G.H.; Friedman, S.; Berg, G.; Zago, V.; Schreier, L. Overproduction of altered VLDL in an insulin-resistance rat model: Influence of SREBP-1c and PPAR- $\alpha$. Clín. Investig. Arterioscler. 2015, 27, 167-174. [CrossRef] [PubMed]

136. Kang, S.-Y.; Lim, G.E.; Kim, Y.K.; Kim, H.W.; Lee, K.; Park, T.-J.; Kim, J. Association between sarcopenic obesity and metabolic syndrome in postmenopausal women: A cross-sectional study based on the Korean National Health and Nutritional Examination Surveys from 2008 to 2011. J. Bone Metab. 2017, 24, 9-14. [CrossRef] [PubMed]

137. Lim, S.; Kim, J.H.; Yoon, J.W.; Kang, S.M.; Choi, S.H.; Park, Y.J.; Kim, K.W.; Lim, J.Y.; Park, K.S.; Jang, H.C. Sarcopenic obesity: Prevalence and association with metabolic syndrome in the Korean Longitudinal Study on Health and Aging (KLoSHA). Diabetes Care 2010, 33, 1652-1654. [CrossRef]

138. Lee, J.; Hong, Y.-P.; Shin, H.J.; Lee, W. Associations of sarcopenia and sarcopenic obesity with metabolic syndrome considering both muscle mass and muscle strength. J. Prev. Med. Public Health 2016, 49, 35. [CrossRef]

139. Scott, D.; Cumming, R.; Naganathan, V.; Blyth, F.; Le Couteur, D.G.; Handelsman, D.J.; Seibel, M.; Waite, L.M.; Hirani, V. Associations of sarcopenic obesity with the metabolic syndrome and insulin resistance over five years in older men: The Concord Health and Ageing in Men Project. Exp. Gerontol. 2018, 108, 99-105. [CrossRef]

140. Sanyal, A.J.; Campbell-Sargent, C.; Mirshahi, F.; Rizzo, W.B.; Contos, M.J.; Sterling, R.K.; Luketic, V.A.; Shiffman, M.L.; Clore, J.N. Nonalcoholic steatohepatitis: Association of insulin resistance and mitochondrial abnormalities. Gastroenterology 2001, 120, 1183-1192. [CrossRef]

141. Donnelly, K.L.; Smith, C.I.; Schwarzenberg, S.J.; Jessurun, J.; Boldt, M.D.; Parks, E.J. Sources of fatty acids stored in liver and secreted via lipoproteins in patients with nonalcoholic fatty liver disease. J. Clin. Investig. 2005, 115, 1343-1351. [CrossRef]

142. Kim, J.K.; Michael, M.D.; Previs, S.F.; Peroni, O.D.; Mauvais-Jarvis, F.; Neschen, S.; Kahn, B.B.; Kahn, C.R.; Shulman, G.I. Redistribution of substrates to adipose tissue promotes obesity in mice with selective insulin resistance in muscle. J. Clin. Investig. 2000, 105, 1791-1797. [CrossRef] [PubMed] 
143. Kim, J.K.; Zisman, A.; Fillmore, J.J.; Peroni, O.D.; Kotani, K.; Perret, P.; Zong, H.; Dong, J.; Kahn, C.R.; Kahn, B.B. Glucose toxicity and the development of diabetes in mice with muscle-specific inactivation of GLUT4. J. Clin. Investig. 2001, 108, 153-160. [CrossRef] [PubMed]

144. Wijarnpreecha, K.; Panjawatanan, P.; Aby, E.; Ahmed, A.; Kim, D. Nonalcoholic fatty liver disease in the over-60s: Impact of sarcopenia and obesity. Maturitas 2019, 124, 48-54. [CrossRef] [PubMed]

145. Buechler, C.; Haberl, E.M.; Rein-Fischboeck, L.; Aslanidis, C. Adipokines in liver cirrhosis. Int. J. Mol. Sci. 2017, 18, 1392. [CrossRef] [PubMed]

146. Budick-Harmelin, N.; Dudas, J.; Demuth, J.; Madar, Z.; Ramadori, G.; Tirosh, O. Triglycerides potentiate the inflammatory response in rat Kupffer cells. Antioxid. Redox Signal. 2008, 10, 2009-2022. [CrossRef]

147. Jiang, W.; Wu, N.; Wang, X.; Chi, Y.; Zhang, Y.; Qiu, X.; Hu, Y.; Li, J.; Liu, Y. Dysbiosis gut microbiota associated with inflammation and impaired mucosal immune function in intestine of humans with non-alcoholic fatty liver disease. Sci. Rep. 2015, 5, 8096. [CrossRef]

148. Kim, G.; Lee, S.E.; Lee, Y.B.; Jun, J.E.; Ahn, J.; Bae, J.C.; Jin, S.M.; Hur, K.Y.; Jee, J.H.; Lee, M.K. Relationship between relative skeletal muscle mass and nonalcoholic fatty liver disease: A 7-year longitudinal study. Hepatology 2018, 68, 1755-1768. [CrossRef]

149. Tovo, C.V.; Fernandes, S.A.; Buss, C.; de Mattos, A.A. Sarcopenia and non-alcoholic fatty liver disease: Is there a relationship? A systematic review. World J. Hepatol. 2017, 9, 326. [CrossRef]

150. Hong, H.C.; Hwang, S.Y.; Choi, H.Y.; Yoo, H.J.; Seo, J.A.; Kim, S.G.; Kim, N.H.; Baik, S.H.; Choi, D.S.; Choi, K.M. Relationship Between Sarcopenia and Nonalcoholic Fatty Liver Disease: The Korean Sarcopenic Obesity Study. Hepatology 2014, 59, 1772-1778. [CrossRef]

(C) 2020 by the authors. Licensee MDPI, Basel, Switzerland. This article is an open access article distributed under the terms and conditions of the Creative Commons Attribution (CC BY) license (http://creativecommons.org/licenses/by/4.0/). 